\title{
Rola Bankowego Funduszu Gwarancyjnego w zakresie bezpieczeństwa i stabilności sektora bankowego w Polsce
}

\section{Wstęp}

Misją Bankowego Funduszu Gwarancyjnego (BFG) jest działanie na rzecz bezpieczeństwa i stabilności banków oraz wzrostu zaufania do systemu bankowego.

Podstawowymi zadaniami Funduszu są:

- ochrona wkładów pieniężnych na rachunkach bankowych osób fizycznych oraz innych podmiotów, które powierzają pieniądze bankom jako instytucjom zaufania publicznego,

- udzielanie pomocy finansowej bankom, które znalazły się w obliczu utraty wypłacalności i podejmują samodzielną sanację,

- wspieranie procesów łączeniowych między bankami,

- gromadzenie informacji oraz bieżąca i okresowa analiza rozwoju sytuacji finansowej banków, ukierunkowana na podejmowanie inicjatyw oraz działań zapobiegających pogłębianiu się występujących zagrożeń.

Istotą działania Funduszu była przede wszystkim ochrona środków finansowych zgromadzonych w bankach przez deponentów oraz zapobieganie upadłościom banków przez wspomaganie procesów restrukturyzacyjnych i sanacyjnych realizowanych przez banki. Te strategiczne zadania wykonywane były w dwóch podstawowych formach:

- zapewnienia deponentom zwrotu ich depozytów w wysokości określonej przez ustawę o BFG - w przypadku upadłości banku,

- finansowego wspomagania procesów sanacyjnych w bankach zagrożonych niewypłacalnością.

Pożyczki zwrotne udzielane były bankom o złej sytuacji finansowej oraz bankom, które podjęły się ratowania banków zagrożonych upadłością przez włączenie ich w swoje struktury organizacyjne. 


\section{System gwarantowania depozytów przez Bankowy Fundusz Gwarancyjny}

System gwarantowania depozytów, obejmujący banki działające w Polsce, stanowi jeden $\mathrm{z}$ głównych elementów bezpiecznego funkcjonowania całego sektora bankowego. Gwarantowanie przez Fundusz środków pieniężnych zdeponowanych $w$ bankach daje społeczeństwu poczucie bezpieczeństwa i buduje zaufanie do sektora bankowego.

Zgodnie z ustawą o BFG, ochronie podlegają depozyty w bankach:

- osób fizycznych,

- osób prawnych,

- jednostek organizacyjnych niemających osobowości prawnej, o ile mają one zdolność prawną,

- szkolnych kas oszczędności i pracowniczych kas zapomogowo-pożyczkowych.

Ochroną nie są objęte depozyty:

- Skarbu Państwa,

- instytucji finansowych, takich jak: banki, domy maklerskie, fundusze emerytalne, fundusze inwestycyjne i podmioty świadczące usługi ubezpieczeniowe,

- podmiotów, które nie są uprawnione do sporządzania uproszczonego bilansu oraz rachunku zysków i strat,

- kadry zarządzającej bankiem oraz jego głównych akcjonariuszy (posiadających co najmniej $5 \%$ akcji banku).

W przypadku ogłoszenia przez sąd upadłości banku uprawnionym osobom wypłacana jest kwota gwarantowana. Środki gwarantowane są wypłacane w złotych według kursu średniego, publikowanego przez NBP, z dnia ogłoszenia przez sąd upadłości banku, przy czym:

- równowartość w złotych do 1000 euro wypłacana jest w 100\%,

- równowartość w złotych od 1000 euro do 22500 euro wypłacana jest w $90 \%$.

W pierwszych dwóch latach funkcjonowania BFG (1995-1997) kwota gwarantowana wynosiła równowartość 3 tys. ECU, po czym była systematycznie podnoszona. Od $2003 \mathrm{r}$., zgodnie z ustawą o BFG, jest to równowartość w złotych 22500 euro, co spełnia wymogi stawiane krajom należącym do Unii Europejskiej.

Prowadzenie działalności gwarancyjnej przez BFG jest możliwe dzięki te$\mathrm{mu}$, że Fundusz może dysponować środkami finansowymi gromadzonymi przez banki w postaci Funduszy Ochrony Środków Gwarantowanych (FOŚG). 
Fundusz ten tworzą banki będące uczestnikami systemu gwarancyjnego. Jego wysokość określa iloczyn sumy zgromadzonych depozytów i stawki procentowej składki, ustalanej corocznie przez Radę Funduszu (maksymalnie 4\%) (tab. 1).

\section{Tabela 1}

Poziom odprowadzanych składek na Fundusz Ochrony Środków Gwarantowanych przez banki w Polsce w latach 1995-2003

\begin{tabular}{|c|c|c|}
\hline \multirow{2}{*}{ Rok } & \multicolumn{2}{|c|}{ Składki na FOŚ [\%] } \\
\cline { 2 - 3 } & $\begin{array}{c}\text { PKO BP S.A., Pekao S.A. } \\
\text { i BGŻ S.A. }\end{array}$ & Pozostale banki \\
\hline 1995 & $0,20^{*}$ & 0,40 \\
\hline 1996 & 0,20 & 0,40 \\
\hline 1997 & 0,09 & 0,18 \\
\hline 1998 & 0,05 & 0,10 \\
\hline 1999 & 0,08 & 0,16 \\
\hline 2000 & 0,40 & 0,40 \\
\hline 2001 & 0,30 & 0,30 \\
\hline 2002 & 0,40 & 0,40 \\
\hline 2003 & 0,40 & 0,40 \\
\hline
\end{tabular}

* $w 1995$ r. obniżona stawka obejmowała również banki spółdzielcze

Źródło: Opracowanie własne na podstawie danych Bankowego Funduszu Gwarancyjnego.

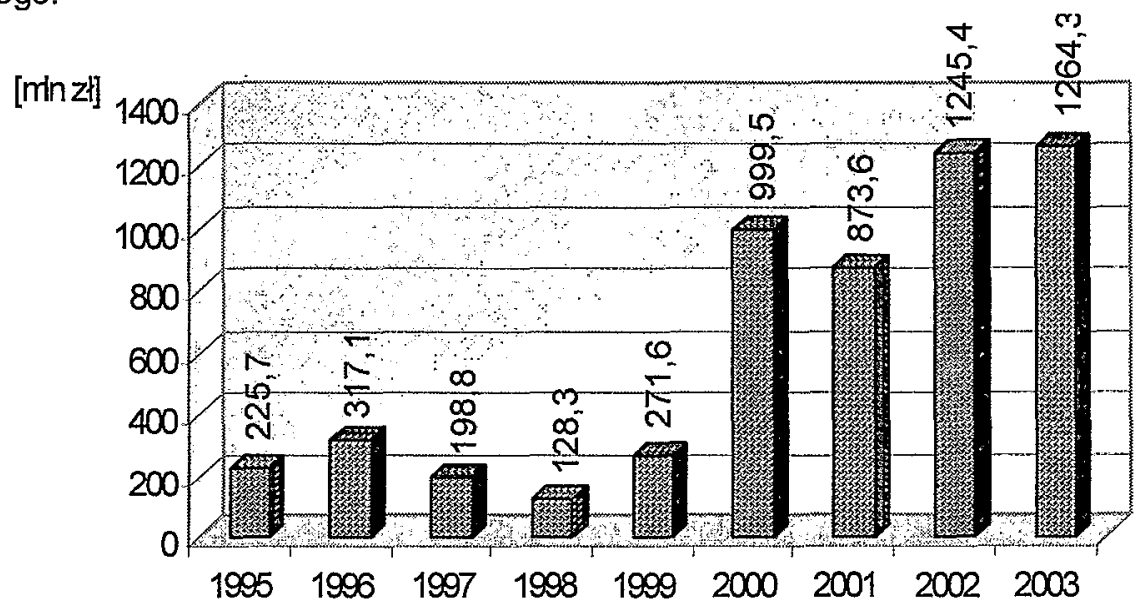

\section{Rysunek 1}

Poziom Funduszu Ochrony Środków Gwarantowanych w sektorze bankowym w Polsce w latach 1995-2004

Żródło: Opracowanie własne na podstawie danych Bankowego Funduszu Gwarancyjnego. 
Środki finansowe odpowiadające utworzonemu Funduszowi pozostaja w bankach w postaci papierów skarbowych bądź bonów pieniężnych NBP. Przynoszą one bankom dochody odsetkowe aż do momentu ich konwersji na środki pieniężne. Ma to miejsce w przypadku upadłości banku, gdy BFG zwraca się do banków o przekazanie środków pieniężnych na wypłaty depozytów gwarantowanych.

Bankowy Fundusz Gwarancyjny w 2003 r. odzyskał z tytułu wierzytelności zgłoszonych do mas upadłości banków kwotę 14456,6 tys. zł. Należności te wynikały z przekazania syndykom w ubiegłych latach środków pieniężnych na wypłaty dla deponentów. Odzyskane środki przeznaczane były wyłącznie na finansowanie kolejnych wypłat kwot gwarantowanych. Dotychczas na ten cel przeznaczono 13 195,0 tys. zł. Ogółem w latach 1995-2003 Fundusz otrzymał z mas upadłości banków kwote 57 078,3 tys. zł, co stanowi 9,1\% wypłat realizowanych na rzecz deponentów w ramach systemu gwarantowania depozytów. W okresie funkcjonowania BFG upadły 94 banki, w tym 5 banków komercyjnych i 89 banków spółdzielczych (rys. 2).

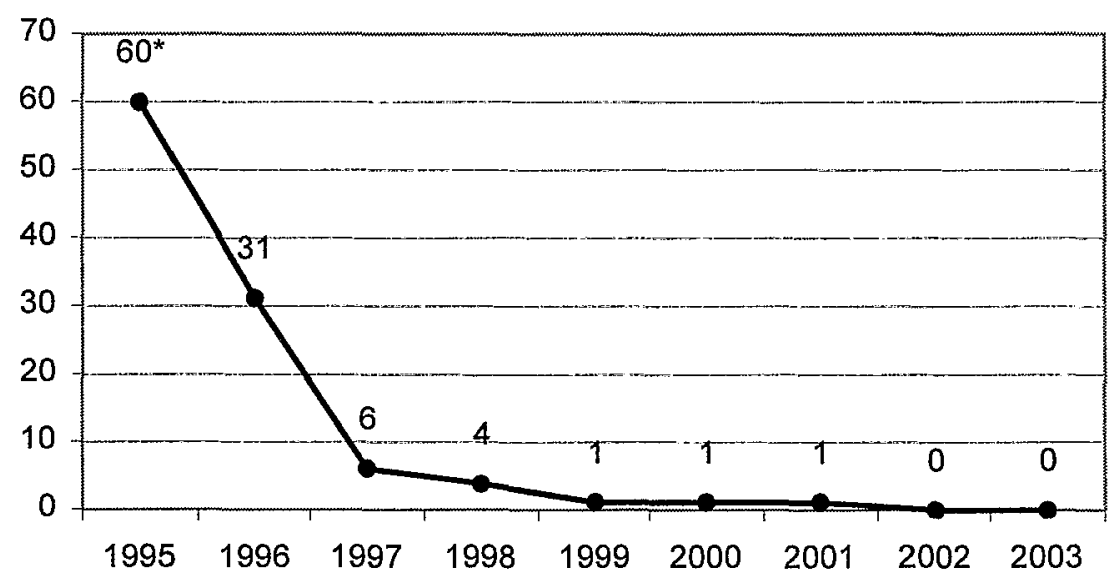

\section{Rysunek 2}

Liczba upadłych banków w Polsce w latach 1995-2003

* w tym 2 banki komercyjne i 48 banków spółdzielczych

Źródło: Opracowanie własne na podstawie danych Bankowego Funduszu Gwarancyjnego.

W latach 1995-2003 wypłaty środków gwarantowanych na rzecz uprawnionych 317,4 tys. deponentów wyniosły $811,7 \mathrm{mln}$ zł, w tym z FOŚG $626 \mathrm{mln}$ zł, tj. $77,2 \%$ ogółu wypłat (tab. 2). Pozostałe $22,8 \%$, tj. $185 \mathrm{mln}$ zł, pochodziło ze środków płynnych upadłych banków i środków odzyskanych z mas upadłości. 
Tabela 2

Poziom wypłat środków gwarantowanych w latach 1995-2003

\begin{tabular}{|l|c|c|c|c|}
\hline \multirow{2}{*}{ Rok } & \multicolumn{2}{|c|}{$\begin{array}{c}\text { Wyplaty środków gwarantowa- } \\
\text { nych [mIn zł] }\end{array}$} & $\begin{array}{c}\text { Stopień wyko- } \\
\text { rzystania } \\
\text { FOSG [\%] }\end{array}$ & $\begin{array}{c}\text { Liczba depo- } \\
\text { nentów [tys. zł] }\end{array}$ \\
\cline { 2 - 4 } & Ogółem & $\begin{array}{c}\text { w tym } \\
\text { z FOSG }\end{array}$ & 38,00 & 88,70 \\
\hline 1995 & 103,70 & 85,80 & 14,90 & 59,40 \\
\hline 1996 & 50,80 & 47,30 & 2,40 & 10,40 \\
\hline 1997 & 6,40 & 4,70 & 3,20 & 6,80 \\
\hline 1998 & 8,20 & 4,10 & 0,00 & 1,60 \\
\hline 1999 & 4,70 & 0,00 & 48,40 & 147,70 \\
\hline 2000 & 625,10 & 484,10 & 0,00 & 2,50 \\
\hline 2001 & 12,20 & 0,00 & 0,00 & 0,28 \\
\hline 2002 & 0,52 & 0,00 & 0,00 & 0,03 \\
\hline 2003 & 0,07 & 0,00 & 106,9 & 317,41 \\
\hline $1995-2003$ & 811,69 & 626,00 & & \\
\hline
\end{tabular}

Źródło: Opracowanie własne na podstawie danych Bankowego Funduszu Gwarancyjnego.

Oprócz gwarantowania depozytów, BFG udzielał bankom pożyczek, gwarancji i poręczeń $w$ celu:

- usunięcia zagrożenia niewypłacalności,

- $\quad$ przejęcia przedsiębiorstwa bankowego, jego części lub połączenia banku $\mathrm{z}$ innym bankiem, jeżeli $\mathrm{w}$ banku przejmowanym powstało niebezpieczeństwo niewypłacalności,

- nabycia udziałów lub akcji banku, w którym powstało niebezpieczeństwo niewypłacalności, przez nowych udziałowców lub akcjonariuszy.

Decyzje o udzieleniu pomocy finansowej były poprzedzane analizą programów naprawczych i oceną realności przyjętych założeń, których wykonanie gwarantowało uzdrowienie banków.

BFG udostępniał bankom środki finansowe przede wszystkim w postaci zwrotnych pożyczek, które były udzielane na warunkach korzystniejszych niż rynkowe. Dotyczyło to zwłaszcza oprocentowania, wysokości prowizji i okresu spłaty.

Od czerwca 2002 r. oprocentowanie pożyczek udzielanych przez Fundusz wynosiło w skali roku od 0,1 do 0,4 stopy redyskonta weksli.

Wysokość prowizji została ustalona na poziomie:

- $\quad 0,3 \%$ kwoty pożyczki dla banków w formie spółki akcyjnej i banków państwowych,

- $\quad 0,1 \%$ kwoty pożyczki dla banków spółdzielczych. 
Pomoc finansowa udzielana była na wniosek zainteresowanego banku. Działalność pomocowa BFG opierała się na następujących założeniach:

- przestrzeganie zasady równości banków w dostępie do środków pomocowych oraz przejrzystości kryteriów i procedur przyznawania pomocy,

- przekazywanie środków pomocowych do dyspozycji banków w celu minimalizowania strat,

- wspieranie procesów konsolidacyjnych i restrukturyzacyjnych przez udzielanie pomocy na przejęcia banków o zagrożonej wypłacalności przez silne banki,

- zapewnienie efektywnej pomocy, m.in. przez określenie w umowach o udzieleniu pożyczki konkretnych przedsięwzięć zmierzających do trwałego odzyskania wypłacalności.

Bankowy Fundusz Gwarancyjny udzielał pomocy finansowej ze środków funduszu pomocowego, tworzonego $z$ obowiazkowych opłat rocznych, wnoszonych przez wszystkie banki objęte obowiązkowym systemem gwarantowania (tab. 3).

W 2004 r. ustalona przez Radę Funduszu stawka obowiązkowej opłaty rocznej wynosiła $0,075 \%$ sumy aktywów, gwarancji i poręczeń ważonych ryzykiem oraz $0,0375 \%$ sumy zobowiazań pozabilansowych pomniejszonych o gwarancje, poręczenia i linie kredytowe ważone ryzykiem.

\section{Tabela 3}

Fundusz pomocowy zarządzany przez BFG w latach 1995-2003

\begin{tabular}{|c|c|c|c|c|c|c|}
\hline \multirow[b]{2}{*}{ Rok } & \multicolumn{2}{|c|}{ Stawka oplaty rocznej [\%] } & \multirow[b]{2}{*}{$\begin{array}{c}\text { Wpłaty } \\
\text { banków } \\
\text { [mIn zł] }\end{array}$} & \multirow[b]{2}{*}{$\begin{array}{l}\text { Wplaty } \\
\text { NBP } \\
\text { [mIn zł] }\end{array}$} & \multirow[b]{2}{*}{$\begin{array}{l}\text { Wpłaty } \\
\text { ogółem } \\
\text { [mln zł] }\end{array}$} & \multirow[b]{2}{*}{$\begin{array}{c}\text { Spłaty } \\
\text { pożyczek } \\
\text { [mln zł] }\end{array}$} \\
\hline & $\begin{array}{l}\text { PKO BP S.A., } \\
\text { Pekao S.A. } \\
\text { i BGŻ S.A.* }\end{array}$ & $\begin{array}{c}\text { Pozostałe } \\
\text { banki }\end{array}$ & & & & \\
\hline 1995 & 0,20 & 0,40 & 173,80 & 0,00 & 173,80 & 0,00 \\
\hline 1996 & 0,20 & 0,40 & 230,00 & 0,00 & 230,00 & 0,00 \\
\hline 1997 & 0,20 & 0,40 & 261,20 & 0,00 & 261,20 & 0,00 \\
\hline 1998 & 0,14 & 0,28 & 209,20 & 89,80 & 299,00 & 3,90 \\
\hline 1999 & 0,12 & 0,24 & 203,40 & 135,60 & 339,00 & 46,20 \\
\hline 2000 & 0,23 & 0,23 & 258,50 & 172,40 & 430,90 & 71,40 \\
\hline 2001 & 0,14 & 0,14 & 158,60 & 158,60 & 317,10 & 148,40 \\
\hline 2002 & 0,08 & 0,08 & 95,50 & 95,50 & 191,00 & 280,30 \\
\hline 2003 & 0,10 & 0,10 & 122,60 & 122,60 & 245,20 & 647,20 \\
\hline $1995-2003$ & - & - & 1712,8 & 774,5 & 2487,2 & 1197,4 \\
\hline
\end{tabular}

*w 1995 r. obniżona stawka obejmowała również banki spółdzielcze Źródło: Opracowanie własne na podstawie danych Bankowego Funduszu Gwarancyjnego. 
Fundusz pomocowy jest zarządzany przez BFG. Banki sa zobowiązane przekazać obowiązkową opłate roczną na początku roku kalendarzowego do 31 marca. Poczynając od 1998 r. swój udział w tworzeniu funduszu pomocowego ma Narodowy Bank Polski. W 1998 r. udział ten wynosił 30\%, w latach 1999 $-2000-40 \%$, natomiast od 2001 r. wynosi aż $50 \%$. Niewykorzystana w danym roku część funduszu pomocowego pozostaje w BFG. Fundusz ten jest dodatkowo zasilany spłatami pożyczek otrzymanych przez banki w latach poprzednich.

Banki spółdzielcze (BS) w Polsce wykorzystywały środki z funduszu pomocowego BFG głównie na samodzielną sanację i procesy łączeniowe (tab. 4). Ogółem $\mathrm{z}$ pomocy finansowej BFG w latach 1996-2004 skorzystały 54 banki spółdzielcze, z czego 29 BS-ów przeznaczyło uzyskane środki finansowe na samodzielną sanację, natomiast 25 BS-ów na procesy łączeniowe.

Ogółem w ramach funduszu pomocowego banki spółdzielcze w Polsce w latach 1996-2004 wykorzystały $283,8 \mathrm{mln} \mathrm{zl}$, z czego $183,0 \mathrm{mln}$ zł przeznaczyły na samodzielną sanację, a 100,8 mln zł na procesy łączeniowe (tab. 4).

Najwięcej środków z funduszu pomocowego Bankowy Fundusz Gwarancyjny przeznaczył dla BS-ów w latach 1997-1999 (odpowiednio 47,1 mln zł, $79,4 \mathrm{mln}$ zł i $45,9 \mathrm{mln} \mathrm{zl}$ ) oraz w 2002 r. (44,8 mln zł).

Ze względu na dobrą sytuację finansową sektora banków spółdzielczych w Polsce oraz zakończony proces konsolidacji w latach 2003-2004 żaden z BS-ów nie skorzystał $\mathrm{z}$ funduszu pomocowego BFG.

Pomoc finansowa BFG dla banków komercyjnych była w latach 1996-2004 ponad 10 razy wyższa niż dla banków spółdzielczych. Pomoc ta objęła 43 banki komercyjne. Najwięcej środków $\mathrm{z}$ funduszu pomocowego banki komercyjne przeznaczyły na samodzielną sanację (2066 mln zł) oraz na przejęcia innych banków komercyjnych (485 $\mathrm{mln}$ zł).

Miarą efektywności pomocy finansowej udzielanej przez BFG dla banków jest:

- kwota środków gwarantowanych, którą wypłaciłby Fundusz w przypadku ogłoszenia upadłości tych banków,

- wartość depozytów podmiotów niefinansowych i budżetów gmin ponad kwoty gwarantowane przez Fundusz oraz wartość środków finansowych banków i Skarbu Państwa, które nie są objęte gwarancjami BFG, a w przypadku upadłości mogłyby zostać utracone.

Dzięki pomocy finansowej udzielanej przez BFG dla banków spółdzielczych i banków komercyjnych została:

- utrzymana na dotychczasowym poziomie liczba placówek bankowych,

- zahamowana redukcja miejsc pracy,

- zachowana dostępność do usług bankowych,

- podwyższona jakość usług bankowych oraz sprawność działania banków. 
Tabela 4

Wykorzystanie środków finansowych z funduszu pomocowego BFG przez banki spółdzielcze i banki komercyjne w Polsce w latach 1996-2004

\begin{tabular}{|c|c|c|c|c|c|c|c|c|c|c|}
\hline \multirow[b]{2}{*}{ Wyszczególnienie } & \multicolumn{2}{|c|}{1996} & \multicolumn{2}{|c|}{1997} & \multicolumn{2}{|c|}{1998} & \multicolumn{2}{|c|}{1999} & \multicolumn{2}{|c|}{2000} \\
\hline & $\begin{array}{c}\text { liczba } \\
\text { banków }\end{array}$ & $\begin{array}{l}\text { kwota } \\
\text { mln zł }\end{array}$ & $\begin{array}{c}\text { liczba } \\
\text { banków }\end{array}$ & $\begin{array}{l}\text { kwota } \\
\text { mln zł }\end{array}$ & $\begin{array}{c}\text { liczba } \\
\text { banków }\end{array}$ & $\begin{array}{l}\text { kwota } \\
\text { min zł }\end{array}$ & $\begin{array}{c}\text { liczba } \\
\text { banków }\end{array}$ & $\begin{array}{l}\text { kwota } \\
\text { min zł }\end{array}$ & $\begin{array}{c}\text { liczba } \\
\text { banków }\end{array}$ & $\begin{array}{l}\text { kwota } \\
\text { mln zł }\end{array}$ \\
\hline 1. Banki spółdzielcze & 4 & 14,00 & 21 & 47,10 & 10 & 79,40 & 9 & 45,90 & 4 & 18,60 \\
\hline a) samodzielna sanacja & 2 & 9,30 & 17 & 37,30 & 5 & 73,10 & 3 & 31,30 & 0 & 0,00 \\
\hline b) procesy lączeniowe & 2 & 4,70 & 4 & 9,80 & 5 & 6,30 & 6 & 14,60 & 4 & 18,60 \\
\hline 2. Banki komercyjne & 5 & 115,20 & 7 & 296,60 & 7 & 139,70 & 2 & 238,20 & 2 & 186,70 \\
\hline a) samodzielna sanacja & 1 & 20,00 & 3 & 240,00 & 2 & 125,00 & 0 & 0,00 & 0 & 0,00 \\
\hline b) przejęcia banków spółdzielczych & 2 & 25,70 & 3 & 6,60 & 5 & 14,70 & 1 & 38,20 & 1 & 1,70 \\
\hline c) przejęcia banków komercyjnych & 2 & 69,90 & 1 & 0,50 & 0 & 0,00 & 1 & 200,00 & 1 & 185,00 \\
\hline d) zakup akcji & 0 & 0,00 & 0 & 0,00 & 0 & 0,00 & 0 & 0,00 & 0 & 0,00 \\
\hline Ogółem & 9 & 129,20 & 28 & 343,70 & 17 & 219,10 & 11 & 284,10 & 6 & 205,30 \\
\hline \multirow[b]{2}{*}{ Wyszczególnienie } & \multicolumn{2}{|c|}{2001} & \multicolumn{2}{|c|}{2002} & \multicolumn{2}{|c|}{2003} & \multicolumn{2}{|c|}{$\therefore \quad 2004$} & \multicolumn{2}{|c|}{$1996-2004$} \\
\hline & $\begin{array}{l}\text { - liczba } \\
\text { banków }\end{array}$ & $\begin{array}{l}\text { kwota } \\
\text { mln zl }\end{array}$ & $\begin{array}{c}\text { liczba } \\
\text { banków }\end{array}$ & $\begin{array}{l}\text { kwota } \\
\text { mln zl }\end{array}$ & $\begin{array}{c}\text { liczba } \\
\text { banków }\end{array}$ & $\begin{array}{l}\text { kwota } \\
\text { mln zł }\end{array}$ & $\begin{array}{c}\text { liczba } \\
\text { banków }\end{array}$ & $\begin{array}{l}\text { kwota } \\
\text { mln zł }\end{array}$ & $\begin{array}{c}\text { liczba } \\
\text { banków }\end{array}$ & $\begin{array}{l}\text { kwota } \\
\text { min zł }\end{array}$ \\
\hline 1. Banki spółdzielcze & 3 & 34,00 & 3 & 44,80 & 0 & 0,00 & 0 & 0,00 & 54 & 283,80 \\
\hline a) samodzielna sanacja & 1 & 12,00 & 1 & 20,00 & 0 & 0,00 & 0 & 0,00 & 29 & 183,00 \\
\hline b) procesy łączeniowe & 2 & 22,00 & 2 & 24,80 & 0 & 0,00 & 0 & 0,00 & 25 & 100,80; \\
\hline 2. Banki komercyjne & 3 & 715,00 & 2 & 88,00 & 14 & 751,00 & 1 & 450,00 & 43 & 2980,40 \\
\hline a) samodzielna sanacja & 2 & 680,00 & 0 & 0,00 & 2 & 551,00 & 1 & 450,00 & 11 & 2066,00 \\
\hline b) przejęcia banków spółdzielczych & 0 & 0,00 & 1 & 58,00 & 0 & 0,00 & 0 & 0,00 & 13 & 144,90 \\
\hline c) przejęcia banków komercyjnych & 0 & 0,00 & 1 & 30,00 & 0 & 0,00 & 0 & 0,00 & 6 & 485,40 \\
\hline d) zakup akcji & 1 & 35,00 & 0 & 0,00 & 12 & 200,00 & 0 & 0,00 & 13 & 235,00 \\
\hline Ogółem & 6 & 749,00 & 5 & 132,80 & 14 & 751,00 & 1 & 450,00 & 97 & 3264,20 \\
\hline
\end{tabular}

Źródło: Opracowanie własne na podstawie danych Bankowego Funduszu Gwarancyjnego. 
Tabela 5

Pomoc finansowa BFG udzielona z Funduszu Restrukturyzacji Banków Spółdzielczych dla BS-ów w Polsce w latach 2001-2004

\begin{tabular}{|c|c|c|c|c|c|c|c|c|c|c|}
\hline \multirow[b]{2}{*}{ Wyszczególnienie } & \multicolumn{2}{|c|}{2001} & \multicolumn{2}{|c|}{2002} & \multicolumn{2}{|c|}{2003} & \multicolumn{2}{|c|}{2004} & \multicolumn{2}{|c|}{$2001-2004$} \\
\hline & $\begin{array}{c}\text { liczba } \\
\text { banków }\end{array}$ & $\begin{array}{l}\text { kwota } \\
\text { mln zk }\end{array}$ & $\begin{array}{c}\text { liczba } \\
\text { banków }\end{array}$ & $\begin{array}{l}\text { kwota } \\
\text { mln zł }\end{array}$ & $\begin{array}{c}\text { liczba } \\
\text { banków }\end{array}$ & $\begin{array}{l}\text { kwota } \\
\text { mln zł }\end{array}$ & $\begin{array}{c}\text { liczba } \\
\text { banków }\end{array}$ & $\begin{array}{l}\text { kwota } \\
\text { min zł }\end{array}$ & $\begin{array}{c}\text { liczba } \\
\text { banków }\end{array}$ & $\begin{array}{l}\text { kwota } \\
\text { mln zf }\end{array}$ \\
\hline 1. Procesy łączeniowe & 66 & 74,30 & 18 & 29,40 & 16 & 27,90 & 11 & 22,90 & 111 & 154,50 \\
\hline 2. Inwestycje & - & - & - & - & 9 & 9,00 & 5 & 6,80 & 14 & 15,80 \\
\hline 3. Zakup akcji banków zrzeszających & - & - & - & - & 14 & 2,70 & 16 & 3,10 & 30 & 5,80 \\
\hline Ogółem & 66 & 74,3 & 18 & 29,4 & 39 & 39,6 & 32 & 32,8 & 155 & 176,1 \\
\hline
\end{tabular}

Źródło: Opracowanie własne na podstawie danych Bankowego Funduszu Gwarancyjnego. 


\section{Pomoc finansowa Bankowego Funduszu Gwarancyjnego dla sektora bankowego w Polsce}

Oprócz środków finansowych z funduszu pomocowego BFG, BS-y mogły uzyskać wsparcie finansowe z Funduszu Restrukturyzacji Banków Spółdzielczych (tab. 5).

Ustawa z dnia 7 grudnia 2000 r. o funkcjonowaniu banków spółdzielczych, ich zrzeszaniu i bankach zrzeszających nałożyła nowe zadania na Bankowy Fundusz Gwarancyjny w zakresie udzielania pomocy bankom spółdzielczym. Zgodnie z powyższą ustawą, Fundusz udzielał pomocy finansowej bankom spółdzielczym na sfinansowanie kosztów łączenia się banków oraz na związane z tym przedsięwzięcia inwestycyjne, w szczególności na:

- unifikacje programów i sprzętu informatycznego,

- ujednolicenie technologii bankowej,

- ujednolicenie procedur finansowo-księgowych,

- unifikację oferty produktów i usług bankowych,

- nabycie akcji banku zrzeszającego.

Źródłem finansowania tej pomocy był Fundusz Restrukturyzacji Banków Spółdzielczych utworzony ze środków pochodzących ze zlikwidowanego Funduszu Rozwoju Banków Spółdzielczych oraz z równowartości wypłaconych z budżetu kwot tytułem obsługi obligacji restrukturyzacyjnych serii „D”, których część została umorzona.

Warunki udzielania pomocy finansowej z Funduszu Restrukturyzacji Banków Spółdzielczych na procesy łączeniowe i inwestycje BS-ów były następujace:

- okres korzystania z pomocy - 3 lata,

- oprocentowanie - 0,1 stopy redyskonta weksli ustalonej przez Radę Polityki Pieniężnej (RPP),

- prowizja-0,1\% kwoty pożyczki,

- warunki spłaty - odsetki płatne kwartalnie, raty kapitałowe - półrocznie.

W dniu 18 grudnia 2003 r. Rada BFG dokonała zmiany warunków pomocy udzielanej na sfinansowanie procesów łączeniowych. Okres korzystania z pomocy został wydłużony do 5 lat, wprowadzono również możliwość zastosowania karencji w spłacie kapitału.

Warunki udzielania pomocy z Funduszu Restrukturyzacji Banków Spółdzielczych na nabycie akcji banków zrzeszających były następujące:

- okres korzystania z pomocy - do 5 lat,

- karencja w spłacie kapitału - do 2 lat,

- oprocentowanie -0,05 stopy redyskonta weksli określonej przez RPP, 
- prowizja - 0,1\% kwoty pożyczki,

- warunki spłaty - odsetki płatne kwartalnie, raty kapitałowe - półrocznie.

W latach 2001-2004 Bankowy Fundusz Gwarancyjny udzielił z Funduszu Restrukturyzacji Banków Spółdzielczych pożyczek dla 155 BS-ów w łącznej kwocie $176,1 \mathrm{mln} z \nmid, \mathrm{z}$ tego na sfinansowanie procesów łączeniowych i realizację inwestycji 170,3 mln zł, a na nabycie akcji banków zrzeszających 5,8 mln zł.

Pożyczki na inwestycje wypłacane z Funduszu Restrukturyzacji Banków Spółdzielczych zostały przeznaczone na:

- unifikację programów i sprzętu informatycznego - 60,9 mln zt,

- ujednolicenie technologii bankowej-3,3 mln zł,

- ujednolicenie procedur finansowo-ksiegowych - 1,2 $\mathrm{mln} \mathrm{z}$,

- unifikację produktów i usług - 0,3 $\mathrm{mln} \mathrm{z}$,

- inne inwestycje związane z konsolidacja - 102,4 mln zł,

- pozostałe wydatki-2,2 mln zł.

W ramach badań ankietowych poproszono kadrę kierowniczą banków spółdzielczych w Polsce o wyrażenie opinii na temat pomocy finansowej, jakiej udzielał Bankowy Fundusz Gwarancyjny (tab. 6). Z rozkładu odpowiedzi respondentów wynika, że pomoc BFG w $66 \%$ badanych BS-ów była niewystarczająca. Tylko $16 \%$ badanych było przeciwnego zdania. Nie miało zdania na ten temat $17 \%$ badanych respondentów, natomiast $1 \%$ badanych nie udzielił odpowiedzi w ogóle.

\section{Tabela 6}

Pomoc finansowa Bankowego Funduszu Gwarancyjnego dla BS-ów w Polsce w opinii ich kadry kierowniczej

\begin{tabular}{|l|c|c|c|c|}
\hline \multirow{2}{*}{ Wyszczególnienie } & \multicolumn{3}{|c|}{ Rodzaj obsługiwanej gminy } & \multirow{2}{*}{ Ogółem } \\
\cline { 2 - 5 } & wiejska & $\begin{array}{c}\text { miejsko- } \\
\text { wiejska }\end{array}$ & miejska & \\
\hline \multirow{2}{*}{ Tak } & 1 & 0 & 3 & 4 \\
\hline \multirow{2}{*}{ Raczej tak } & $3 \%$ & $0 \%$ & $9 \%$ & $4 \%$ \\
\hline \multirow{2}{*}{ Raczej nie } & 3 & 3 & 6 & 12 \\
\hline \multirow{2}{*}{ Nie } & 4 & $8 \%$ & $19 \%$ & $12 \%$ \\
\hline \multirow{2}{*}{ Trudno powiedziec } & $13 \%$ & 15 & 6 & 25 \\
\hline \multirow{2}{*}{ Brak odpowiedzi } & 13 & $12 \%$ & $19 \%$ & $25 \%$ \\
\hline \multirow{2yyyy}{*}{ Ogółem } & $41 \%$ & $33 \%$ & 16 & 41 \\
\cline { 2 - 5 } & $31 \%$ & 6 & $17 \%$ & $41 \%$ \\
\hline
\end{tabular}

Źródło: Badania własne, $\mathrm{chi}^{2}=22,84, \mathrm{p}=0,0114$. 
Najwięcej negatywnych odpowiedzi na temat pomocy finansowej BFG wobec BS-ów odnotowano w bankach z gmin miejsko-wiejskich (75\%) i miejskich (69\%), natomiast najmniej z gmin wiejskich (54\%).

Najwyższy odsetek respondentów wskazujących, że pomoc finansowa BFG dla BS-ów była wystarczająca stwierdzono w bankach $\mathrm{z}$ gmin miejskich $(28 \%)$, natomiast najniższy odsetek takich odpowiedzi wystapił $\mathrm{w}$ bankach z gmin miejsko-wiejskich (8\%).

\section{Podsumowanie i wnioski końcowe}

1. System gwarantowania depozytów obsługiwany przez BFG stanowił jeden z głównych elementów bezpiecznego funkcjonowania całego sektora bankowego $\mathrm{w}$ Polsce. Gwarantował on społeczeństwu poczucie bezpieczeństwa oraz stwarzał zaufanie do tego sektora.

2. Pomoc finansowa oferowana przez BFG dla BS-ów z funduszu pomocowego oraz Funduszu Restrukturyzacji Banków Spółdzielczych zapobiegała ich upadkowi oraz wspomagała proces ich restrukturyzacji. Sektor banków spółdzielczych w Polsce wykorzystywał środki $\mathrm{z}$ funduszu pomocowego głównie na procesy naprawcze oraz procesy łączeniowe. Ogólem w latach 1996-2004 z pomocy finansowej BFG w kwocie 283,8 mln zł skorzystały 54 banki spółdzielcze. Banki komercyjne wykorzystały środki finansowe z funduszu pomocowego na ogólną kwotę $2980,4 \mathrm{mln}$ zł, z czego najwięcej środków przeznaczyły na samodzielną sanację (2066 mln zl) i przejęcia innych banków komercyjnych (485,4 mln zl). Pomocą finansową ze strony BFG objęto 43 banki komercyjne. Dzięki temu zahamowany został proces upadłości banków, warunkujący: utrzymanie sieci placówek bankowych, miejsc pracy, jak również łatwiejszy dostęp ludności do produktów i usług bankowych.

3. Bankowy Fundusz Gwarancyjny przez udzielanie pomocy finansowej wspomagał procesy restrukturyzacji w BS-ach. Największe kwoty środków finansowych zostały wydatkowane na unifikację programów i sprzętu informatycznego oraz inwestycje związane $z$ procesem konsolidacji. Mankamentem pomocy finansowej udzielanej przez BFG była jednak zbyt mała liczba BS-ów objętych tą pomocą. Z badań ankietowych wynika, że aż $66 \%$ badanych respondentów stwierdziło, że pomoc finansowa BFG dla ich banków była niewystarczająca. Odmienne zdanie na ten temat miało $16 \%$ badanych. Przyczyną niewystarczającej pomocy finansowej oferowanej przez BFG wobec bankom spółdzielczym były ograniczone fundusze oraz dość skomplikowane procedury, według których BS-y mogły ubiegać się o pomoc finansową w BFG. 


\section{Literatura}

BUGAJNY T., 2002: System oceny ryzyka związanego z pożyczkami udzielonymi bankom przez Bankowy Fundusz Gwarancyjny wykorzystywany do celów monitorowania. Bezpieczny Bank 4(19).

JARZĘBSKI M., ZARACHOWICZ H., 2004: Pomoc Bankowego Funduszu Gwarancyjnego ze środków Funduszu Restrukturyzacji Banków Spółdzielczych. Bezpieczny Bank $1(22)$.

RAK R., 2001: Nowy Fundusz Pomocowy BFG dla banków spółdzielczych. Bezpieczny Bank 1/2(12/13).

Ustawa z dnia 14 grudnia 1994 r. o Bankowym Funduszu Gwarancyjnym. DzU z 2000 r. $\mathrm{Nr}$ 9, poz. 131.

\section{The Bank Guarantee Fund's Role in Ensuring the Security and Stability of the Banking Sector in Poland}

\section{Abstract}

In the 1995-2002 period, the Bank Guarantee Fund ensured safety of deposits held by customers at banks, up to the zloty equivalent of euro 22,250 in the case of banks' bankruptcy. Moreover, the Bank Guarantee Fund was providing financial assistance to banks for their restructuring and consolidation. Due to this help, the number of bank branches and customer service offices remained at a stable level, the reduction in employment was haltered, quality of bank services was increased and banks operational performance was improved. 